\title{
PERAN GENERASI BINA BANGSA (GENBI) DALAM MEMBERDAYAKAN MASYARAKAT PERBATASAN JAGOI BABANG KAB BENGKAYANG
}

\author{
Syarifah Ema Rahmaniah \\ Universitas Tanjungpura (UNTAN) Pontianak \\ ema_rahmaniah@yahoo.com
}

\begin{abstract}
This article discusses the role of GENBI in increasing the community participation in developing the Bidai craft in Jagoi Babang Bengka using incubator business program in cooperation with Bank Indonesia. This paper uses qualitative methods by using in depth interview towards Bidai craftsmen in Jagoi Babang and the community leaders who are competent about the issue of border development. Using Arstein Ladder method, it is identified that there is a significant increase of community participation in the business incubatorprogram. It is on the fifth and the sixth phase, namely partnership andplacation. The Synergy cooperation among government, the private sector and the community is needed in order to increase public participation. Government affirmative action becomes important to be pursued to control the bidai craft productivity and create a socio economic network among the craftsmen.
\end{abstract}

Keywords: community participation, craft splint, affirmative action

\begin{abstract}
Abstrak
Tulisan ini membahas peran GENBI dalam upaya meningkatkan partisipasi masyarakat dalam mengembangkan kerajinan Bidai di Jagoi Babang Kab Bengkayang melalui program inkubator bisnis bekerjasama dengan Bank. Indonesia. Tulisan ini menggunakan metode kualitatif dengan menggunakan wawancara mendalam terbadap pengrajin bidai di Jagoi Babang dan tokoh masyarakat yang kompeten dengan permasalahan pembangunan perbatasan. Berdasarkan model partisipasi Ladder Arstein teridentifikasi tingkatan partisipasi masyarakat dalam program inkubator bisnis berada pada tahap kelima yaitu kemitraan dan tahap keenam, penentraman. Sinergisitas kerjasama antara pemerintah, sektor swasta dan masyarakat sangat diperlukan dalam upaya meningkatkan partisipasi masyarakat. Tindakan afirmatif pemerintah menjadi penting untuk diupayakan dengan mengontrol produktivitas kerajinan bidai dan menciptakan jaringan sosial ekonomi para pengrajin bidai.
\end{abstract}

Kata Kunci: partisipasi masyarakat, kerajinan Bidai, tindakan afirmatif 


\section{Pendahuluan}

Berdasarkan data Kalimantan Barat dalam Angka tahun 2012, garis kemiskinan di provinsi Kalimantan Barat tahun 2010 adalah 189.407 rupiah per kapita perbulan. Garis kemiskinan terendah berada di kabupaten Kayong Utara yaitu 158.862 rupiah perkapita perbulan dan tertinggi adalah Kabupaten Sintang yaitu 253.855 rupiah perkapita per bulan. Sementara itu jumlah penduduk miskin di Provinsi Kalimantan Barat tahun 2010 berjumlah sekitar 428,76 ribu orang dengan persentase penduduk miskinnya sekitar 9.02 persen. Kabupaten yang memiliki penduduk miskin terbanyak adalah Kabupaten Ketapang dengan 58,50 ribu orang, sedangkan persentase penduduk miskin terbanyak terdapat di Kabupaten Landak yaitu sekitar 14,06 persen (Kalimantan Barat Dalam Angka $2012: 423$ )

Adapun perhitungan indeks pembangunan manusia (IPM) tahun 2011 (angka sementara) IPM tertinggi adalah Provinsi DKI Jakarta sebesar 77,85 diikuti posisi kedua Provinsi Sulawesi Utara sebesar 76,51 dan Riau sebesar 76,50. Sementara IPM Provinsi Kalimantan Barat sebesar 69,53 yang secara Nasional peringkatnya berbeda pada posisi 28 dari 33 Provinsi di Indonesia (Kalimantan Barat Dalam Angka 2012 : 429). Dalam konteks perbatasan Provinsi Kalimantan Barat masih memiliki keterbatasan sarana dan prasarana dibandingkan dengan negara tetangga sehingga orientasi masyarakat dan mobilitas barang dan orang cenderung lebih besar dari Wilayah Kalimantan Barat menuju Sarawak Malaysia (Rahmaniah 2011). Sehingga produktivitas masyarakat perbatasan Kalimantan Barat menjadi sangat bergantung kepada negara tetangga

Berdasarkan fenomena pasar di kawasan perbatasan Kalimantan Barat, terlihat masyarakat pendatang yang menguasai aktivitas ekonomi, sementara hanya sedikit masyarakat lokal yang menikmati aktivitas pasar ini. Hal ini semakin terasa memberatkan masyarakat lokal, karena aktivitas pasar tidak memiliki perlindungan hukum yang jelas sehingga tidak banyak memberi manfaat bagi masyarakatperbatasan. Belumada perlindungan hasilkarya penduduk pribumi seperti kerajinan bidai, sehingga hasil karya adat lokal ini dengan mudah dieksploitasi oleh pihak terkait. Jika terjadi sengketa 
dalam aktivitas di pasar masyarakat lokal lebih memilih jalan damai dan menghindari solusi melalui lembaga hukum/peradilan maupun polisi. Mereka khawatir jika masalah ini sampai ke pengadilan, mereka akan kehilangan pelanggan mereka. Permasalahan serupa terjadi di desa Jagoi Babang, yang berbatasan dengan Malaysia khususnya di distrik Serikin. Masyarakat Jagoi memiliki potensi kerajinan bidai sebagai kerajinan khas yang terbuat dari rotan, hasilnya berupa tas,perabot dapur, tikar dan keperluan alat rumah tangga lainnya. Di Jagoi Babang terdapat banyak sekali kerajinan bidai yang dijual ke Serikin Serawak-Malaysia. Kerajinan Bidai merupakan salah satu industri rumah tangga yang banyak terdapat di Desa Jagoi, Kecamatan Jagoi Babang Kabupaten Bengkayang. Bidai merupakan kerajinan yang berasal dari suku Dayak Bekati. Bahan baku bidai adalah rotan Saga, kulit kayu kapuak atau tembaran. Hasil akhirnya berupa tikar, tas, perabot, penghias dinding, taplak meja, sajadah dan lainnya dengan motif Dayak yang kental. Pasarannya adalah Malaysia melalui jalur perbatasan Jagoi Babang - Serikin.

Namun kerajinan bidai ini belum memperlihatkan inovasi motif yang signifikan, karena dikerjakan secara tradisional. Selain itu pemasaran hasil kerajinan bidai ini belum memiliki daya tawar yang baik sesuai dengan standar internasional ketika dipasarkan di pasar Serikin yang beroperasi setiap hari pasar yaitu Sabtu dan Minggu. Bahkan yang lebih mengagetkan lagi berdasarkan data yang telah peneliti dapatkan, pedagang di Serikin mengakui bahwa kerajinan yang dihasilkan ini merupakan hasil kerajinan masyarakat Malaysia padahal realitanya ini dikerjakan oleh masyarakat pengrajin bidai di Jagoi Babang. Dengan demikian upaya mendapatkan hak kekayaan intelektual kerajinan bidai menjadi penting dengan cara menyadarkan masyarakat Jagoi Babang tentang potensi dari produktivitas kearifan lokal mereka dan mengkontruksi model jaringan sosioekonomi kerajinan bidai Jagoi Babang.

Terdapat beberapa penelitian tentang pembangunan di perbatasan yang dilakukan oleh Suratman (2008) dalam tesis PhD Fakultas Ekonomi Universitas Indonesia Jakarta dengan judul Kawasan Perbatasan dan Pembangunan Daerah. Karya ini berfokus pada pengembangan perbatasan dengan menggunakan pendekatan sistem neraca sosioekonomi (SNSE) dalam perspektif 
ekonomi. Hasil penelitian Suratman menjelaskan bahwa di daerah Kalimantan Barat khususnya di daerah perbatasan masih tingginya jumlah penduduk miskin di daerah perbatasan. Suratman juga menjelaskan bahwa kebijakan pengembangan kawasan perbatasan tidak mengganggu distribusi pendapatan di Kalimantan Barat, bahkan hal ini berkontribusi pada pemerataan distribusi pendapatan walaupun masih sedikit. Selanjutnya, beliau juga menyatakan kebijakan pengembangan kawasan perbatasan juga memberikan dampak kepada peningkatan pendapatan neraca sektor produksi.

Hermansyah (2011) dalam analisis antropologi hukum terhadap perdagangan lintas batas di Kalimantan Barat (upaya pencarian model dan pola perlindungan hukum). Penelitian ini menjelaskan tentang perlindungan hukum aktivitas perdagangan di daerah perbatasan. Hermansyah menjelaskan tentang konsep pasar dalam perspektif ekonomi, antropologi, politik dan hukum. Menurutnya pasar memiliki multi peran yang tidak hanya berperan menjalankan aktivitas ekonomi namun menjadi tempat berlangsungnya proses interaksi budaya sehingga dengan mudah orang akan melihat terjadinya perubahan nilai, ide, norma, kepercayaan dan aktivitas berpola dari manusia dalam masyarakat. Pasar di perbatasan tidak hanya berasal dari masyarakat lokal tetapi juga masyarakat pendatang bahkan dari negara tetangga.

Pernyataan Hermansyah ini searah dengan kajian Siburian (2002) yang menjelaskan krisis ekonomi yang terjadi pada tahun 1997 di Indonesia justru memberi keuntungan bagi masyarakat perbatasan terutama masyarakat yang bergerak dalam bidang bisnis dan pertanian dengan adanya "pasar kaget" di sekitar perbatasan Entikong. Ia menjelaskan penyebab hal ini terjadi: (1) adanya "pasar kaget" di sekitar perbatasan Entikong (2) tingkat ekonomi masyarakat Malaysia yang jauh lebih tinggi dibandingkan masyarakat Indonesia yang menyebabkan terjalinnya interaksi ekonomi yang saling menguntungkan (3) warga Indonesia mampu menyediakan komoditas barang dengan kualitas yang tidak terlalu rendah dan mampu bersaing dengan barang-barang yang dijualbelikan di Malaysia. Namun, keberkahan masa krisis ekonomi ini hanya dirasakan sebagian kelompok masyarakat di perbatasan terutama masyarakat pendatang yang membuka usaha bisnis dan jasa, sehingga masyarakat lokal masih tetap miskin dan tidak merasakan keuntungan ini. 
Sementara itu Wu (2001:22-33) mengidentifikasi tiga pendekatan pembangunan daerah perbatasan: pertama, perencanaan dengan mendahulukan membangun infrastruktur (infrastructure led) sebagai investasi sebelum aktivitas ekonomi dimulai. Kedua, mendahulukan investasi sektor swasta (investment led), dan ketiga, mendahulukan program-program dan kebijakan (policy led) yang bertujuan untuk memudahkan pengembangan kawasan perbatasan. Wu menggunakan pendekatan perencanaan wilayah dengan fokus utama pembangunan perbatasan lebih kepada perbaikan infrastruktur fisik sebagai salah satu usaha membangun daerah perbatasan. Selanjutnya kajian Ishikawa (2010) yang dilakukan di kawasan Teluk Melano (Malaysia) dan Temajuk (Indonesia) mengungkapkan dinamika kehidupan yang terjadi antara dua komunitas yang berbeda secara politik namun memiliki banyak kesamaan secara sosiobudaya. Meskipun memiliki perbedaan secara politik namun aktivitas sosioekonomi antara dua komunitas dapat bertahan dengan baik.

Berdasarkan hasil penelitian terdahulu yang pernah dilakukan menunjukkan bahwa pemodelan keseimbangan umum adalah metode yang menjanjikan efek, sebagai metode dasar pemodelan equilibirum umum yang mantap, meskipun pembangunan baru selalu dibuat. Namun, analisis lebih lanjut mengenai dampak proyek-proyek investasi yang besar di tingkat awal masih diperlukan. Dibandingkan dengan beberapa penelitian mengenai masyarakat perbatasan tampaknya terdapat perbedaan dengan kajian peneliti seperti dari obyek kajian, cara analisis, pendekatan metodologi, serta lokasi penelitian. Persamaannya adalah terletak pada faktor keterbatasan sumber daya, sarana dan prasarana serta kapasitas dari kebijakan pemerintah dalam mendukung dan menghambat rencana pengembangan kawasan perbatasan. Masukan dari observasi awal dan beberapa kajian yang telah dilakukan memberi elaborasi dan pengayaan wawasan terhadap fokus penelitian.

Oleh karena itu peneliti tertarik dan menganggap penting untuk dilakukan penelitian ini sebagai langkah awal memberikan kontribusi kepada pemerintah kabupaten dan solusi kebijakan dengan mengembangkan model pemberdayaan masyarakat perbatasan dalam mengembangkan usaha kerajinan bidai di Kab Bengkayang, 
sehingga dapat membentuk jaringan sosioekonomi kerajinan bidai sebagai sumber pendapatan masyarakat setempat. Maka pendekatan yang dikembangkan dalam mengelola perbatasan ialah dengan meningkatkan kesadaran masyarakat potensi sosioekonomi kerajinan bidai dan keterampilan masyarakat sehingga masyarakat tidak menjadi penonton dalam pembangunan perbatasan.

\section{Metode Penelitian}

\section{Subjek Penelitian}

Subjek penelitian ini adalah para pengrajin dan pedagang kerajinan bidai di Jagoi Babang Kabupaten Bengkayang.

\section{Objek Penelitian}

Objek penelitian ini adalah bagaimana peran Generasi Bina Bangsa (GENBI) dalam upaya meningkatan keterampilan dan teknologi kerajinan Bidai yang berorientasi pada pelestarian pranata lokal masyarakat setempat di perbatasan direalisasikan. Lokasi penelitian ini di dilaksanakan di Kec Jagoi Babang Kab Bengkayang yang merupakan wilayah perbatasan darat yang kaya dengan kekayaan hutan. Kawasan ini merupakan salah satu pusat pertumbuhan ekonomi terutama sekali kerajinan bidai sebagai hasil dari produktivitas masyarakat sesuai dengan kearifan lokal yang ada.

Penelitianinimerupakan pengembanganmodelpemberdayaan masyarakat berbasis kearifan lokal dalam upaya mengembangkan usaha kerajinan bidai di Kab Bengkayang. Tehnik pengumpulan data melalui observasi langsung dan wawancara mendalam yang diawali dengan pengembangan model pemberdayaan masyarakat berbasis kearifan lokal untuk mengembangkan usaha kerajinan bidai di Kab Bengkayang dan dilanjutkan kepada tahapan implementasi model pemberdayaan masyarakat berbasis kearifan lokal untuk mengembangkan usaha kerajinan bidai di Kab Bengkayang.

\section{Kronologis berdirinya Generasi Muda Indonesia (GENBI)}

Bermula pada saatobrolan santaiketika berbuka puasa bersama selepas acara penandatanganan perjanjian kerjasama pemberian Beasiswa antara Bank Indonesia dengan Universitas Indonesia, 
Universitas Islam Negeri Syarif Hidayatullah, Institut Pertanian Bogor dan Universitas Negeri Jakarta pada 3 Agustus 2011. Dari hasil pertemuan tersebut maka muncullah ide untuk terus menjalin komunikasi dan interaksi agar saling menginspirasi, memotivasi dan saling berbagi informasi agar kegiatan sesama penerima beasiswa BI dapat bersinergi dan berkoordianasi mengingat keanggotaan atau mahasiswa penerima bea siswa BI terdiri dari beberapa perguruan tinggi di Indonesia.

Pada saat itu muncul beberapa kesepakatan, diantaraya adalah; nama dan lambang untuk Komunitas Penerima Beasiswa Bank Indonesia adalah Generasi Baru Indonesia (GENBI), membentuk tim perumus dan kelompok kerja yang bertugas untuk merencanakan pertemuan umum dan deklarasi yang akan dilaksanakan pada 11 November 2011 (11-11-11) serta menyusun rancangan Konstitusi Organisasi (Statuta, AD dan ART). Semangat pembentukan Komunitas Mahasiswa Penerima Beasiswa Bank Indonesia bergulir ke berbagai daerah melalui kegiatan pertemuan umum yang juga di isi dengan Learning Forum dalam bentuk Dialog $\&$ Diskusi Terbuka yang membahas kondisi terkini di bidang makro dan mikro ekonomi serta sosial-politik dengan narasumber yang kompeten di bidangnya. Komunitas mahasiswa penerima beasiswa Bank Indonesia kemudian dibentuk di seluruh Perguruan Tinggi termasuk di Kalimantan Barat. Mahasiswa penerima beasiswa Bank Indonesia ini menjadi wahana serta sarana pengembangan kepemimpinan mahasiswa berbasis kampus yang diperuntukan dan dikelola oleh para mahasiswa penerima beasiswa Bank Indonesia dalam rangka akselerasi dan optimalisasi potensi bibit - bibit unggul muda Indonesia (www.genbi.go.id).

\section{Rekonstruksi Pemberdayaan Masyarakat Perbatasan}

Dalam mengejar ketertinggalan pembangunan khususnya disektor ekonomi, strategi dan kebijakan pembangunan di Indonesia di masa lalu diarahkan untuk mencapai tingkat pertumbuhan setinggitingginya. Caranya dengan memberikan perhatian khusus terhadap perkembangan investasi, modal, dan teknologi guna meningkatkan skala ekonomi. Kondisi ini membuat partisipasi masyarakat menjadi 
rendah, sehingga membuat masyarakat tercabut (uproot) dari lingkaran pembangunan itu sendiri. Sebagai dampak pembangunan terjadilah ketimpangan dan kesenjangan sosial-ekonomi yang semakin melebar, mencakup antar daerah dan antar golongan.

Oleh sebabitu perubahan strategi pembangunan konvensional menjadi model strategi pembangunan masyarakat berkelanjutan sangat dirasakan perlu dengan mengurangi peran atau campur tangan negara dan memberikan kepercayaan dan keterlibatan masyarakat dalam pembangunan. Mengacu hal di atas minimnya peran negara berarti, dibukanya kesempatan masyarakat untuk terlibat dalam proses pembuatan kebijakan pembangunan dan turut melaksanakannya. Hanya masyarakat yang memahami kondisi, keinginan dan permasalahan sebenarnya mereka terutama dalam pembangunan. Proses perencanaan kebijakan menjadi bersifat bottom-up berbasis demokrasi bahwa pembangunan adalah dari rakyat, untuk rakyat dan juga oleh rakyat. Ini berarti dalam pelaksanaan pembangunan peranan pemerintah pusat diserahkan kepada pemerintah daerah dengan memberikan kekuasaan dan kebebasan kepada pemerintah daerah dalam melaksanakan pembangunan daerahnya. Dengan demikian tercipta kerjasama yang seimbang antara pemerintah, masyarakat dan swasta dalam mensukseskan pembangunan yang direncanakan, dimana pembangunan ini tidak hanya menekankan pembangunan ekonomi tetapi juga menekankan pembangunan manusia.

Midgley (2005:21) membedakan tiga ketegori pencapaian kesejahteraan, pertama, sejauh mana masalah sosial itu dapat diatasi. Kedua, sejauh mana kebutuhan dapat terpenuhi dan ketiga, sejauh mana kesempatan untuk meningkatkan taraf hidup dapat diperoleh. Semuanya ini bisa diciptakan dalam kehidupan bersama, baik ditingkat keluarga, komunitas maupun masyarakat secara luas. Selanjutnya konsep kesejahteraan dalam terminologiakademis adalah kesejahteraan sosial yang mengalami pergeseran dalam pemahaman dan penggunaannya. Kesejahteraan sosial itu menunjukkan kondisi kehidupan yang baik, terpenuhinya kebutuhan bahan untuk hidup, kebutuhan spiritual, kebutuhan sosial yang teratur, konflik dalam kehidupan dapat dikendalikan, keamanan dapat dijamin, keadilan dapat ditegakan dan berkurangnya kesenjangan sosial ekonomi. 
Dari segi sosial, mereka ramah dengan orang lain, mengutamakan keluarga dan menghindari konflik. Secara psikologis, mereka diikat oleh keyakinan dan tidak mengeluh. Secara hiegenis, makanan yang dikonsumsi tidak mengandung unsur-unsur lemak tinggi, secara fisik, mereka pada umumnya tidak pernah berhenti berkegiatan dan berolah raga. Oleh karena itu kesejahteraan itu lebih banyak dilihat secara qualitatif dari sekedar memenuhi kebutuhan material yang dikonstruksikan oleh pasar.

Pemberdayaan juga dipengaruhi oleh pemikiran Paulo Freire yang memperkenalkan istilah konsientisasi (conscientization) (Freire, 1970). Konsientisasi adalah suatu proses pemahaman dan penumbuhan kesadaran terhadap situasi yang sedang terjadi berkaitan dengan isu politik, ekonomi, maupun sosial. Menurut Freire seseorang dikatakan sudah berada dalam tahap konsientisasi, jika ia sanggup menganalisis masalah mereka, mengidentifikasi sebabsebabnya, menetapkan prioritas dan memperoleh pengetahuan baru secara mandiri. Oleh karena itu pemberdayaan dipahami sebagai kemampuan individu untuk mengontrol lingkungannya dengan mencapai kesadaran kritis dalam diri seseorang dan menggunakan apa yang didengar, dilihat, dan dialami untuk memahami apa yang sedang terjadi dalam kehidupannya.

Latama et.al (2002: 4) menambahkan bahwa pemberdayaan masyarakat dianggap bersifat komprehensif jika memiliki lima karakteristik utamanya seperti (1) berdasar kepentingan masyarakat lokal; (2) berorientasi kepada peningkatan kesejahteraan; (3) berbasis kemitraan; (4) bersifat holistik ; dan (5) berkelanjutan. Dengan demikian pemberdayaan masyarakat berbasis lokal adalah perencanaan dan pelaksanaan pemberdayaan yang dilakukan di daerah setempat dan melibatkan sumber daya manusia setempat. Sehingga hasilnya dapat turut dinikmati oleh masyarakat lokal bukan sekedar menjadi penonton dan pemerhati di luar sistem, tetapi justru melibatkan mereka dalam pembangunan itu sendiri.

Pemberdayaan menurut Kartasasmita (1996: 159-160) harus dilakukan melalui tiga arah. Pertama, menciptakan suasana iklim yang memungkinkan potensi masyarakat berkembang. Ini berarti setiap manusia atau masyarakat telah memiliki potensi, sehingga pada saat 
melaksanakan langkah pemberdayaan diusahakan agar mendorong dan membangkitkan kesadaran masyarakat akan pentingnya mengembangkan potensi-potensi yang telah dimiliki. Kedua, memperkuat potensi atau daya yang dimiliki masyarakat (empowering). Artinya, langkah pemberdayaan diusahakan melalui tindakan nyata seperti pendidikan, pelatihan, peningkatan kesehatan, pemberian modal, informasi, lapangan kerja, pasar, serta prasarana lainnya. Ketiga, melindungi hak cipta hasil karya masyarakat (protection). Ini berarti dalam pemberdayaan masyarakat perlu diupayakan langkah-langkah yang mencegah persaingan secara tidak seimbang serta praktik eksploitasi yang kuat terhadap yang lemah. Usaha ini dilakukan melalui keberpihakan dan adanya aturan atau kesepakatan yang jelas dan tegas untuk melidungi kelompok yang lemah atau yang belum berkuasa.

\section{Diagram 1}

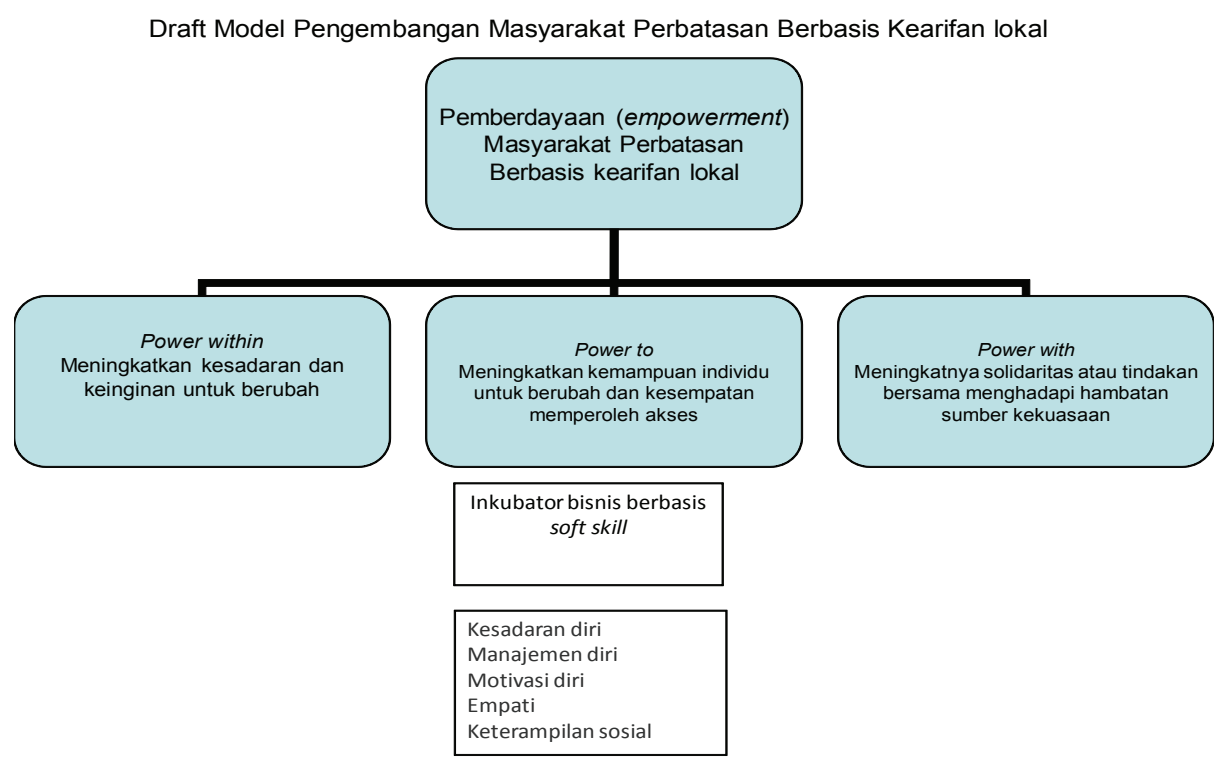

\section{Model Pengembangan Masyarakat Perbatasan}

Sumber : olahan peneliti

Agar dalam setiap aktivitas pembangunan benar-benar menyentuh kepentingan masyarakat, maka dalam proses 
perencanaan pembangunan harus mengutamakan partisipasi masyarakat. Sebagaimana yang dipaparkan Soetrisno (1995: 208) pertama, partisipasi rakyat dalam pembangunan bukanlah mobilisasi rakyat dalam pembangunan. Partisipasi rakyat dalam pembangunan adalah dalam kerjasama antara rakyat dan pemerintah merancang, melaksanakan, dan membiayai pembangunan.Kedua, untuk membangun dan mewujudkan partisipasi rakyat dalam pembangunan harus diciptakan suatu perubahan dan persepsi pemerintah terhadap pembangunan. Ketiga, untuk membangkitkan partisipasi masyarakat dalam pembangunan dibutuhkan sikap toleransi dari pejabat daerah terkait kritik, pikiran alternatif yang muncul dalam masyarakat sebagai akibat dari dinamika pembangunan itu sendiri, karena kritik dan pikiran alternatif itu merupakan satu bentuk dari partisipasi rakyat dalam pembangunan.

Selanjutnya untuk mengukur tingkatan partisipasi masyrakat Arstein (1969: 116-224) membagi 8 tingkatan partisipasi: pertama, manipulation yaitu tingkatan partisipasi yang paling rendah karena masyarakathanyadipakainamanya sajasebagaianggotadalamberbagai lembaga. Tidak ada peran yang nyata, karena hanya diselewengkan. Kedua, theraphy. Pada tingkatan ini, masyarakat diperlakukan seolaholah seperti proses penyembuhan pasien penyakit jiwa dalam kelompok terapi. Masyarakat terlibat dalam banyak aktivitas, namun hal tersebut hanya ditujukan untuk mengubah pola pikir masyarakat dari informasi atau rekomendasi. Ketiga, informing merupakan tahap pemberian informasi kepada masyarakat tentang hak-hak, tanggung jawab dan berbagai pilihan. Biasanya hanya diberikan secara satu arah, dari penguasa ke rakyat, tanpa adanya kemungkinan jawaban. Pada tingkat ini masyarakat diberi limpahan kekuasaan untuk mempengaruhi rencana untuk kepentingan masyarakat. Biasanya dilakukan dengan melalui media, brosur, poster dan tanggapan atas pertanyaan.Keempat, konsultasi yaitu mengundang pendapat masyarakat, setelah memberi informasi kepada mereka. Bila negosiasi tidak disertai dengan cara-cara partisipasi yang lain, maka tingkat keberhasilannya akan rendah, mengingat tidak adanya jaminan kepedulian terhadap ide-ide masyarakat. Tahap ini biasanya dilakukan dengan cara pertemuan lingkungan studi tentang pola pikir masyarakat dan dengar pendapat publik. Kelima, placation/ 
penetraman. Pada tingkat placation masyarakat telah memiliki pengaruh meskipun masih ditentukan oleh pemerintah di beberapa sektor. Usul-usul dari komunitas berpenghasilan rendah dapat dikemukakan, tetapi sering tidak diperhitungkan karena kemampuan dan posisinya relatif rendah atau jumlah mereka terlalu sedikit bila dibandingkan dengan anggota-anggota lembaga pemerintah lain. Keenam, partnership/kemitraan. Dalam tingkatan ini masyarakat dan pemegang kewenangan menjadi mitra dan melakukan kesepakatan bersama sehingga terjadi kesepakatan pembagian tanggung jawab dalamperencanaan, penentuankeputusan, penyusunankebijaksanaan dan solusi berbagai permasalahan yang dihadapi. Setelah adanya kesepakatan tersebut maka tidak diperbolehkan adanya perubahanperubahan yang dilakukan secara instant. Ketujuh, delegated power. Pada tingkat ini masyarakat diberi limpahan kekuasaan untuk membuat keputusan pada rencana atau program tertentu. Masyarakat berhak menentukan program-program yang bermanfaat untuk mereka. Untuk menyelesaikan masalah, pemerintah harus mengadakan tawarmenawar tanpa adanya tekanan. Kedelapan, citizen control. Masyarakat telah memiliki kekuatan untuk menentukan dan mengelola program atau institusi yang terkait dengan kepentingan mereka. Komunitas memiliki kekuasaan penuh di bidang kebijaksanaan, aspek-aspek manajemen dan dapat mengadakan pembicaraan dengan pihakpihak luar yang ingin melakukan perubahan.

Dengan demikian partisipasi masyarakat merupakan salah satu tujuan pembangunan. Oleh karena itu kemampuan pihak terkait sangat dibutuhkan khususnya dalam rangka menggalang, menggerakkan dan menumbuh kembangkan semangat partisipasi masyarakat. Mengutamakan masyarakat dalam berbagai kegiatan pembangunan merupakan tugas pemerintah yang cukup berat dan membutuhkan waktu yang agak lama dalam pencapaiannya. Selain itu keterlibatan masyarakat dapat lebih terlaksana apabila perancanaan pembangunan itu sendiri barorientasi kepada kepentingan masyarakat. Berikut adalah gambaran derajat dan mekanisme partipasi masyarakat dalam pengembangan Kerajinan Bidai di desa Jagoi Babang yang diterangkan dalam tabel 1: 


\section{Tabel 1}

Derajat Partisipasi

\begin{tabular}{|c|c|c|}
\hline $\begin{array}{c}\text { Derajat } \\
\text { partisipasi }\end{array}$ & Tangga partisipasi & Mekanisme partisipasi \\
\hline \multirow{4}{*}{ Kuasa warga } & 8. kendali warga & - \\
\hline & $\begin{array}{l}\text { 7.kuasa yang } \\
\text { didelegasikan }\end{array}$ & - \\
\hline & 6.kemitraan & $\begin{array}{l}\text { Program inkubator bisnis } \\
\text { oleh GENBI bekerja } \\
\text { sama dengan BI }\end{array}$ \\
\hline & 5.Penentraman & Pelatihan dari dekranasda \\
\hline \multirow[b]{2}{*}{ Tanda partisipasi } & 4.Konsultasi & Musrenbang desa \\
\hline & 3.Pemberian informasi & $\begin{array}{l}\text { - Penyampaian } \\
\text { undangan musrenbang } \\
\text { desa. } \\
\text { - Penyampaian } \\
\text { program pelatihan } \\
\text { kewirausahaan dan } \\
\text { bantuan simpan } \\
\text { pinjam }\end{array}$ \\
\hline \multirow[t]{2}{*}{ Non Partisipasi } & 2.Terapi & $\begin{array}{l}\text { Kunjungan dekranasda } \\
\text { dan kepala desa dalam } \\
\text { program kewirausahaan } \\
\text { masyarakat desa }\end{array}$ \\
\hline & 1.Manipulasi & - \\
\hline
\end{tabular}

Sumber : olahan peneliti 
Searah dengan tabel 1 diatas, tingkatan partisipasi masyarakat perbatasan masih berada dalam tahap ke enam yaitu kemitraan dimana program inkubator bisnis telah dilaksanakan oleh GENBI bekerja sama dengan BI. Tahap kelima, placation (penentraman) dimana masyarakat telah memiliki pengaruh meskipun masih ditentukan oleh pemerintah daerah di beberapa sektor seperti pengajuan modal, penentuan mitra kerja dan pelatihan yang dilakukan oleh Dekranasda Kab Bengkayang. Dalam tingkatan ini usulan masyarakat dapat dikemukakan namun tidak diperhitungkan karena kemampuan dan posisinya relatif rendah. Tahap yang ke empat adalah tahap konsultasi dengan adanya keberdaan Musrenbang desa di desa Jagoi Babang, meskipun telah ada beberapa Musrenbang desa namun belum memfokuskan pada perbincangan pengembangan kerajinan Bidai, jikapun ada perbincangan berkaitan pengelolaan peningkatan infrastruktrur desa dan kegiatan perekonomian secara umum. Tahap ketiga adalah pemberian informasi berupa penyampaian undangan Musrenbang desa dan penyampaian program pelatihan kewirausahaan dan bantuan simpan pinjam. Tahap kedua adalah terapi yaitu adanya kunjungan pejabat atau pengelola Dekranasda dan kepala desa dalam program masyarakat desa terutama sekali program-program yang berkaitan dengan pengembangan kerajinan tangan di Jagoi Babang.

\section{Pengembangan Model inkubator Bisnis Berbasis soft skill}

Secara umum konsep soft skill dipahami sebagai bagian dari sifat kepribadian dan kemampuan yang diperlukan agar dapat menjalankan pekerjaan secara efektif. Helmlinger (tth:2) menjelaskan soft skill merupakan sifat kepribadian dan menjadi kunci meraih kesuksesan yang berfungsi untuk meningkatkan efektivitas kerja. Menurut Sharma (2009) soft skill adalah seluruh aspek dari generic skills yang termasuk dalam elemen kognitif yang sangat berhubungan dengan non academic skills. Sharma mengidentifikasi terdapat tujuh soft skill yang penting untuk dikembangkan yaitu keterampilan berkomunikasi, keterampilan berfikir dan menyelesaikan masalah, kekuatan kerja tim, belajar sepanjang hayat dan pengelolaan informasi, keterampilan wirausaha, etika, moral dan profesionalisme, dan keterampilan kepemimpinan. Selanjutnya Sharma membagi 
skill individu kedalam dua kategori skill yang harus dimiliki dan skill yang baik dimiliki seperti dijelaskan dalam tabel 2 berikut ini:

\section{Tabel 2}

\section{Kategori SKILL}

\begin{tabular}{ccc}
\hline & Sub skills & Sub skills \\
Soft skills & Elemen yang harus & Elemen yang baik \\
& dimiliki & dimiliki \\
\hline
\end{tabular}

Kemampuan berkomunikasi
- Kemampuan menyampaikan ide secara jelas, efektif dan meyakinkan baik oral maupun tertulis

- Kemampuan untuk mempraktikkan keterampilan untuk mendengar dengan baik dan memberi tanggapan

- Kemampuan berprestasi secara jelas dan meyakinkan kepada audien.
- Kemampuan untuk menggunakan teknologi selama presentasi

- Kemampuan untuk berdiskusi dan mengakhiri dengan consensus

- Kemampuan berkomunikasi dengan individu yang mempunyai latar belakanng budaya yang berbeda

- Kemampuan menggunakan keterampilan non-oral

- Keterampilan untuk menularkan kemampuan komunikasinya ke orang lain. 


\begin{tabular}{|c|c|c|}
\hline $\begin{array}{l}\text { Keterampilan } \\
\text { berfikir dan } \\
\text { menyelesaikan } \\
\text { masalah }\end{array}$ & $\begin{array}{l}\text { - Kemampuan untuk } \\
\text { mengidentifikasi dan } \\
\text { menganalisis masalah } \\
\text { dalam situasi sulit dan } \\
\text { melakukan justifikasi } \\
\text { - Kemampuan } \\
\text { memperluas dan } \\
\text { memperbaiki } \\
\text { keterampilan berfikir } \\
\text { seperti menjelaskan, } \\
\text { menganalisis dan } \\
\text { mengevaluasi diskusi. } \\
\text { - Kemampuan } \\
\text { mendapatkan ide } \\
\text { dan mencari solusi } \\
\text { alternatif. }\end{array}$ & $\begin{array}{l}\text { - Kemampuan berfikir } \\
\text { lebih luas. } \\
\text { - Kemampuan untuk } \\
\text { membuat kesimpulan } \\
\text { berdasarkan } \\
\text { pembuktian yang valid. } \\
\text { - Kemampuan } \\
\text { untuk menerima } \\
\text { dan memberikan } \\
\text { tanggungjawab } \\
\text { sepenuhnya. } \\
\text { - Kemampuan untuk } \\
\text { memahami seseorang } \\
\text { dan mengakomodasikan } \\
\text { ke dalam suasana kerja } \\
\text { yang beragam }\end{array}$ \\
\hline Kerja dalam tim & $\begin{array}{l}\text { - Kemampuan untuk } \\
\text { membangun hubungan } \\
\text { berinteraksi dan } \\
\text { bekerja secara efektif } \\
\text { dengan lainnya. } \\
\text { - Kemampuan untuk } \\
\text { memahami dan } \\
\text { berperan sebagai } \\
\text { pemimpin dan } \\
\text { pengikut (anggota) } \\
\text { - Kemampuan } \\
\text { untuk memahami, } \\
\text { menghargai dan } \\
\text { menghormati prilaku, } \\
\text { pemahaman dan } \\
\text { keyakinan orang lain }\end{array}$ & $\begin{array}{l}\text { - Kemampuan untuk } \\
\text { memberikan kontribusi } \\
\text { terhadap perencanaan } \\
\text { dan mengkoordinasikan } \\
\text { kerja group. } \\
\text { - Bertanggungjawab } \\
\text { terhadap keputusan } \\
\text { group. }\end{array}$ \\
\hline
\end{tabular}




\begin{tabular}{|c|c|c|}
\hline $\begin{array}{l}\text { Belajar sepanjang } \\
\text { hayat dan } \\
\text { pengelolaan } \\
\text { informasi }\end{array}$ & $\begin{array}{l}\text { - Kemampuan untuk } \\
\text { mengelola informasi } \\
\text { yang relevan dari } \\
\text { berbagai sumber. } \\
\text { - Kemampuan untuk } \\
\text { menerima ide-ide baru. }\end{array}$ & $\begin{array}{l}\text { - Kemampuan untuk } \\
\text { mengembangkan } \\
\text { keinginan untuk } \\
\text { menginvestigasi dan } \\
\text { mencari pengetahuan. }\end{array}$ \\
\hline $\begin{array}{l}\text { Keterampilan } \\
\text { kewirausahaan }\end{array}$ & $\begin{array}{l}\text { - Kemampuan untuk } \\
\text { mengidentifikasi } \\
\text { peluang kerja }\end{array}$ & $\begin{array}{l}\text { - Kemampuan untuk } \\
\text { mengajukan proposal } \\
\text { peluang bisnis } \\
\text { - Kemampuan untuk } \\
\text { membangun, } \\
\text { mengeksplorasi dan } \\
\text { mencari peluang bisnis } \\
\text { dan kerja. } \\
\text { - Kemampuan untuk } \\
\text { berwirausaha sendiri. }\end{array}$ \\
\hline $\begin{array}{l}\text { Etika,moral dan } \\
\text { profesionalisme }\end{array}$ & $\begin{array}{l}\text { - Kemampuan untuk } \\
\text { memahami krisis } \\
\text { ekonomi, aspek } \\
\text { sosial budaya secara } \\
\text { profesional } \\
\text { - Memampuan analisis } \\
\text { untuk membuat } \\
\text { keputusan pemecahan } \\
\text { masalah terkait dengan } \\
\text { etika. }\end{array}$ & $\begin{array}{l}\text { - Kemampuan untuk } \\
\text { mempraktikkan etika } \\
\text { prilaku disamping } \\
\text { mempunyai tanggung } \\
\text { jawab terhadap } \\
\text { masyarakat. }\end{array}$ \\
\hline $\begin{array}{l}\text { Keterampilan } \\
\text { kepemimpinan }\end{array}$ & $\begin{array}{l}\text { - Mempunyai } \\
\text { pengetahuan teori } \\
\text { dasar kepemimpinan } \\
\text { - Kemampuan untuk } \\
\text { memimpin suatu } \\
\text { proyek }\end{array}$ & $\begin{array}{l}\text { - Kemampuan untuk } \\
\text { memahami dan menjadi } \\
\text { alternative pemimpin } \\
\text { dan pengikut } \\
\text { - Kemampuan } \\
\text { mensupervisi anggota } \\
\text { suatu group. }\end{array}$ \\
\hline
\end{tabular}

Sumber : Sharma 2009 
Dengan demikian skill yang harus dimiliki masyarakat perbatasan adalah skill atau kemampuan kewirausahaan terutama sekali kemampuan mengelola sumber daya alam yang ada sehingga memiliki nilai ekonomi yang tinggi. Terlebih lagi dalam upaya menghadapi tantangan bermulanya perdagangan bebas di tingkat ASEAN Community pada tahun 2015 tentu persaingan global akan semakin besar. Oleh karena itu dibutuhkan kemampuan soft skill seperti ketangguhan,kesabaran,ketegaran dan jiwa kewirausahaan pengrajin Bidai. Berdasarkan hasil penelilitan ini dapat diketahui bahwa jiwa kewirausahaan dapat terbentuk dengan baik melalui inkubator bisnis. Inkubator bisnis ini berfungsi untuk meningkatkan kemampuan teknis maupun managerial. Bentuk inkubator bisnis yang dapat dikembangkan adalah memberikan pengetahuan praktis yang lebih banyak dibandingkan dengan teori sehingga jiwa kewirausahaan tidak hanya diberikan secara teoritik namun diimbangi dengan pengetahuan praktek seperti metode pengepakan dan pengiriman barang yang efektif dan efisien, serta melakukan kombinasi produk yang menyesuaikan kebutuhan pasar.

\section{Peran GENBI Kal-Bar dalam Pengembangan Inkubator Bisnis}

Inkubasi bisnis adalah proses pembinaan bagi usaha kecil dan atau pengembangan produk baru yang dilakukan oleh inkubator bisnis dalam hal penyediaan sarana dan prasarana usaha, pengembangan usaha dan dukungan manajemen serta teknologi. Sedangkan inkubator bisnis adalah lembaga yang bergerak dalam bidang penyediaan fasilitas dan pengembangan usaha, baik manajemen maupun teknologi bagi usaha kecil dan menengah untuk meningkatkan dan mengembangkan kegiatan usahanya dan atau pengembangan produk baru agar dapat berkembang menjadi wirausaha yang tangguh dan atau produk baru yang berdaya saing dalam jangka waktu tertentu (Juknis Pengembangan Kewirausahaan Nomor: 81.3/Kep/M.KUKM /VIII/).

Secara sistemik, inkubasi bisnis merupakan suatu wahana transformasi pembentukan sumberdaya manusia yang tidak atau kurang kreatif dan produktif menjadi sumberdaya manusia yang memiliki motivasi wirausaha secara kreatif, inovatif, produktif dan 
kooperatif sebagai langkah awal dari penciptaan wirausaha yang memiliki keunggulan kompetitif dan komparatif serta memiliki visi dan misi kedepan yang jelas. Inkubasi bisnis memiliki cakupan komunitas yang saling berintegrasi dalam operasi dan aktivitas, yaitu: wirausahawan, perguruan tinggi, lembaga pembiayaan, konsultan bisnis, penasihat hukum bisnis (business legal counsel), swasta, BUMN/BUMD, pemerintah melalui instansi-instansi teknis terkait, dan lembaga swadaya masyarakat. Dengan demikian program inkubator bisnis ini adalah wujud nyata dari tahap pemberdayaan masyarakat yang dilaksanakan oleh Bank Indonesia bermitra dengan masyarakat salah satunya adalah GENBI.

Berkaitan dengan tahap pemberdayaan Sulistiyani (2004:83) mengidentifkasi tahapan pemberdayaan sebagai berikut : (1) Tahap penyadaran dan pembentukan perilaku menuju perilaku sadar dan peduli sehingga merasa membutuhkan peningkatan kapasitas diri (2) Tahap transformasi kemampuan berupa wawasan pengetahuan, kecakapan ketrampilan agar terbuka wawasan dan memberikan keterampilan dasar sehingga dapat mengambil peran di dalam pembangunan. (3) Tahap peningkatan kemampuan intelektual, kecakapan keterampilan sehingga terebentuklah insiatif dan kemampuan inovatif untuk mengantarkan pada kemandirian

Pada tahap penyadaran program inkubator bisnis berbasis soft skill dilakukan dengan memberikan sentuhan penyadaran agar masyarakat dapat mengidentifikasi kebutuhan dan kondisi saat ini sehingga dapat merangsang kesadaran perlunya memperbaiki kondisi saat ini dan menciptakan masa depan yang lebih baik. Pada tahap kedua adalah tahap transformasi pengetahuan dan keterampilan terutama keterampilan kewirausahaan yang berbasis soft skill sehingga keterampilan dapat berlangsung baik, penuh semangat, inovatif dan berjalan efektif. Masyarakat mempelajari pengetahuan dan keterampilan yang memiliki relevansi pengembangan produktivitas, kualitas dan pemasaran kerajinan bidai. Selanjutnya tahap terakhir tahap pengayaan dan peningkatan kecakapan keterampilan yang diperlukan agar dapat membentuk kemampuan 
kemandirian masyarakat. Kemandirian masyarakat ini ditandai dengan kemampuan inisiatif dan kreativitas dalam pengembangan kerajinan bidai. Berdasarkan hasil wawancara dan observasi lapangan tahapan keberdayaan masyarakat kawasan perbatasan berada dalam 2 tahapan yaitu:

\section{Tabel 3}

Tahapan Keberdayaan Masyarakat Perbatasan

\begin{tabular}{|c|c|c|c|}
\hline $\begin{array}{l}\text { Tahapan } \\
\text { afektif }\end{array}$ & Tahapan kognitif & $\begin{array}{c}\text { Tahapan } \\
\text { psikomotorik }\end{array}$ & $\begin{array}{l}\text { Tahapan } \\
\text { kognitif }\end{array}$ \\
\hline $\begin{array}{l}\text { Semangat } \\
\text { kesadaran dan } \\
\text { kepedulian }\end{array}$ & $\begin{array}{l}\text { Mengembangkan } \\
\text { pengetahuan dasar }\end{array}$ & $\begin{array}{l}\text { Mengembangkan } \\
\text { keterampilan dasar }\end{array}$ & $\begin{array}{l}\text { Inisiatif untuk } \\
\text { mengambil } \\
\text { peran dalam } \\
\text { pembangunan }\end{array}$ \\
\hline $\begin{array}{l}\text { Merasa } \\
\text { membutuhkan } \\
\text { kemandirian }\end{array}$ & $\begin{array}{l}\text { Mendalami } \\
\text { pengetahuan pada } \\
\text { tingkat yang lebih } \\
\text { tinggi }\end{array}$ & $\begin{array}{l}\text { Memperkaya } \\
\text { variasi } \\
\text { keterampilan }\end{array}$ & $\begin{array}{l}\text { Berposisi secara } \\
\text { mandiri untuk } \\
\text { membangun diri } \\
\text { dan lingkungan }\end{array}$ \\
\hline
\end{tabular}

Sumber : Sulistiani (2004:84-85)

Berdasarkan tabel 3, tingkat kesadaran dan kemampuan masyarakat perbatasan dalam upaya mengembangkan sumber daya alam berada pada pola perkembangan linier. Artinya kondisi masyarakat perbatasan bukan pada kondisi belum memiliki kesadaran dan kepedulian pentingnya inkubator bisnis untuk meningkatkan produktivtas mereka. Namun justru sebaliknya masyarakat justru telah memiliki tingkat kesadaran dan kepedulian pentingnya pengembangan pengetahuan dan keterampilan dasar kewirausahaan dalam pengembangan kerajinan bidai. Namun sayang program inkubator bisnis belum dilaksanakan secara optimal di kawasan perbatasan, kalaupun ada masih dalam bentuk konvensional yaitu hanya sekedar pengenalan pentingnya keterampilan dan pengetahuan kewirausahaan secara teoritik namun dalam kegiatan konkret berupa upaya membentuk jaringan pasar masih belum dilaksanakan. 
Untuk meningkatkan partisipasi masyarakat dalam pengembangan kerajinan bidai di Jagoi Babang, perlu dibentuk suatu kelembagaan masyarakat lokal yang bersinergi dengan jejaring antarkelembagaan untuk mencapai kemandirian masyarakat lokal. Menurut Lubis (2012 dalam Nasdian 2014: 244) proses pemberdayaan yang perlu dilakukan oleh perusahaan dalam hal ini adalah Bank Indonesia dan pemerintah daerah adalah :1.advokasi; 2.pengorganisasian komunitas;3.pengembangan jejaring;4. pengembangan kapasitas ;5. komunikasi, informasi dan edukasi.

GENBI Kalbar yang terdiri dari komunitas mahasiswa penerima beasiswa Bank Indonesia wilayah Kalimantan Barat telah melalukan beberapa tahapan dalam pengembangan masyarakat. Selain bertujuan untuk meningkatkan kepekaan sosial serta menumbuhkan semangat dan jiwa pengabdian terhadap masyarakat. Para mahasiswa penerima beasiswa BI ini telah dilatih sedemikian rupa dengan berbagai keterampilan yang menyesuaikan kebutuhan dan permasalahan masyarakat sekitarnya. Mereka diharapkan mampu menjadi pemimpin yang menjulang ke atas dan mampu mengakar ke bawah hingga terbangunnya mental pembelajaran yang bertitik pada proses perbaikan diri yang berkelanjutan. Fokus utama kegiatan Genbi ada tiga lini yaitu bidang sosial, enterpreneur (kewirausahaan) dan kesehatan.

Pada tahun 2014 berbagai kegiatan telah dilaksanakan GENBI seperti kegiatan bakti sosial di pondok pesantren di beberapa kawasan di Kalimantan Barat terutama kawasan sekitar perbatasan yang masih berada dalam garis kemiskinan dibanding kawasan bukan perbatasan. GENBI juga menyalurkan sumbangan untuk kebakaran di Seluas Kabupaten Bengkayang, membangikan bibit sayuran dan bingkisan kepada anak-anak sekolah di Kubu Raya. Selain itu GENBI turut menyumbangkan sejumlah bibit sayuran ke petani yang ada di Desa Mekar Sari, Kabupaten Kubu Raya yang bertujuan mendorong para petani agar bisa mandiri dan menjadi pengusaha sayur mayur yang sukses. Pada saat kebakaran hutan terjadi GENBI turut membagikan 4 ribu masker kepada pengendara di Bundaran Degulist Universitas Tanjungpura Pontianak sebagai antisipasi menyebarnya penyakit ISPA. GENBI juga turut aktif melaksanakan kegiatan pelatihan pengembangan kemampuan vokasi masyarakat dan generasi muda 
seperti pelatihan inkubator bisnis,pelatihan dan pengembangan program animasi dan pelatihan peningkatan produksi dan pemasaran makanan ringan khas Kalimantan Barat. Lebih menarik lagi banyak kader dan alumni GENBI berhasil membuka usaha sendiri setelah mengikuti pelatihan tersebut.

Gerakan GENBI ini tentunya menjadi model yang konstruktif agar dapat meningkatkan kesadaran dan kemampuan masyarakat perbatasan untuk mengelola hasil alam menjadi hasil atau karya yang memiliki nilai ekonomi yang tinggi. Keberadaan Genbi turut membuka wawasan masyarakat perbatasan untuk lebih optimal meningkatkan produktivitas dan kreatifitas mereka terutama sekali berkaitan dengan peningkatan ekonomi kreatif yang berbasis kearifan lokal seperti kerajinan Bidai. Selain melakukan pelatihan inkubator bisnis Genbi juga aktif melaksanakan program pendidikan non formal lainnya seperti gerakan membaca bagi masyarakat perbatasan, membuat perpustakaan alternatif di perpustakaan dan kegiatan ceramah agama dan gerakan belajar al quran kepada masyarakat perbatasan yang beragam Islam.

Pilhan pendekatan keagamaan karena kebanyakan mahasiswa penerima beasiswa ini adalah berlatarbelakang sebagai mahasiswa aktivis organisasi keagamaan di kampus dan di luar kampus seperti aktivis HMI, PMII dan KAMMI. Pendekataan keagamaan ini menjadi lebih efektif digunakan dan dengan mudah diterima oleh masyarakat karena materi dan metode yang disampaikan menggunakan pendekatan ekonomi yaitu pelatihan inkubator bisnis sehingga isu-isu agama, moral dan kecintaan kepada NKRI dengan mudah dapat terserap oleh masyarakat. Program inkubator bisnis ini akhirnya dengan mudah dikenalkan kepada masyrakat perbatasan juga dapat membantu mengatasi permasalah perekonomian masyrakat bahkan masyarakat dapat meningkatkan produktivitasnya tidak hanya disektor ekonomi kreatif namun juga di sektor yang lain seperti pertanian dan perkebunan. Pendekatan inilah yang peneliti katakan sebagai model inkubator bisnis berbasis soft skill, sebuah keterampilan entrepernership yang tidak berfokus 
pada produksi namun juga memastikan hasil produksi tersebut memberikan dampak positif terhadap lingkungan dan kehidupan sosial masyarakat perbatasan yang berkelanjutan implikasinya.

Dengan demikian yang menjadi fokus utama dalam pembangunan perbatasan adalah bagaimana menciptakan kondisi lingkungan, baiklingkungan politik maupunlingkungan sosial-budaya yang dapat mendorong lahirnya manusia kreatif dan produktif. Pembangunan tidak hanya terkait dengan produksi dan distribusi barang-barang material, namun pengembangan lebih bermakna kepada suatu kesadaran dan aktivitas yang dapat menciptakan kondisi yang membuat manusia mampu mengembangkan kreativitasnya.

\section{Kesimpulan}

Penelitian ini diharapkan dapat mengembangkan modal sosioekonomi masyarakat dan mengurangi tingkat ketergantungan dan orientasi masyarakat terhadap negara jiran. Hal ini dilakukan dengan menciptakan sinergisitas kerjasama antara pemerintah, sektor swasta dan masyarakat. Dalam hal ini pemerintah hendaknya mampu memberikan tindakan afirmatif, mengontrol produktivitas dan harga barang. Selanjutnya peran swasta adalah meningkatkan jaminan dan jaringan sosiaekonomi pagi para pengrajin bidai. Sementara itu masyarakat umum dan para pengrajin Bidai hendaknya mampu meningkatkan partisipasi mereka menjadi lebih mandiri dan produktif dengan mengikuti pelatihan vocational dalam meningkatkan jiwa wirausaha agar mampu menghadapi tantangan dan harapan nasional dan global. Para peserta diajarkan tentang bagaimana membuat hasil produk mereka agar bisa menarik melalui perubahan bentuk produk, menciptakan produk turunannya dan cara bagaimana mengemas produk dalam bentuk lain sehingga mampu menarik konsumen untuk membelinya. Hasil dari pelatihan ini ialah terinventarisirnya beberapa produk turunan yang potensial, kelompok-kelompok industri yang serumpun, teknik dan cara pengemasan yang efisien, serta alat-alat pendukung yang diperlukan. 


\section{Daftar Pustaka}

Arstein, Sherry.R. 1969. A Ladder of Citizen Participation. JAIP 35 (4) :216-224

Freire, Paulo.1970. Pedagogy of the Oppressed. New York: Penguin Books

Hermansyah. 2011. Analisis antropologi hukum terhadap perdagangan lintas batas di Kalimantan Barat (upaya pencarian model dan pola perlindungan hukum). Jurnal dinamika bokum, V. 11 No $1: 1-9$

Helmlinger,Will. Tanpa tahun.Do you employee possess the right competencies ?diakses pada tanggal 20 Desember 2014 dari http://hiring.inc.com/columns.html

Ishikawa, Niboru. 2010. Between Frontiers Nation and Identity in a Southeast Asia Borderland. Singapore: Nus press

Juknis Pengembangan Kewirausahaan Nomor: 81.3/Kep/M. KUKM /VIII. Kalimantan Barat Dalam Angka.2012. Bappeda dan BPS Prov Kalimantan Barat

Kartasasmita, Ginanjar.1996. Pembangunan untuk Rakyat, Memadukan Pertumbuhan dan Pemerataan. Jakarta: CIDES.

Latama,Gunarto.et.all.2002. Pengelolaan wilayah pesisir berbasis masyarakat di

Indonesia http://tumoutou.net/70205123.group2 123.htm diakses pada 20/Maret/2007 
Midgley,James. 2005. Pembangunan Sosial;Perspektif Pembangunan dalam Kesejahteraan Sosial. Jakarta : Direktorat Perguruan Tinggi Agama Islam Depag RI

Nasdian, Fredian Tonny.2014. Pembangunan Masyrakat. Jakarta: Yayasan Obor

Rahmaniah, Ema. 2011. Pembangunan perbatasan dan implikasinya terhadap keamanan masyarakat (community security) di perbatasan Kalimatan Barat" Pemakalah pendamping pada Focus Group Discussion kerjasama FISIP UNTAN dan MPR RI mengenai ” wawasan Nusantara dan Ketahanan Nasional dalam menjaga Keutuhan NKRI pada 27 September 2011

Sharma, Archna .2009. Professional Development for Teachers. Diakses pada Tanggal 25 Desember 2010 dari http:// schoolofeducators.com/2009/02/importance-ofsoft0skillsdevelopment-in-education

Siburian,Robert. 2002. Entikong: Daerah tanpa Krisis Ekonomi di Perbatasan Kalimantan Barat-Sarawak. Antropologi Indonesia .No 67: 87-93

Soetrisno,Lukman. 1995. Upaya Menciptakan Pembangunan Berkelanjutan dalam Otonomi Daerah: Peluang dan Tantangan. Jakarta: Pustaka Sinar Harapan.

Sulistiani, Ambar Teguh. 2004. Kemitraan dan Model-Model Pemberdayaan. Yogjakarta: Gaya Media

Suratman, Edi. 2008. Kawasan Perbatasan dan Pembangunan Daerah. Pontianak: UNTAN Press 
Wu, Chung- Tong. 2001. Cross-border development in a changing World: Redefining regional development policies. Dalam Edgington, David W. et.al.(pnyt). New Regional Development Paradigms. Vol 2:21-36. London:Greenwood Press.

www.genbi.go.id diakses pada tanggal 25/ Desember /2014 